\title{
A Radar-Based Climatology of Mesoscale Convective Systems in the United States
}

\author{
Alex M. HABERLIE \\ Department of Geography and Anthropology, Louisiana State University, Baton Rouge, Louisiana \\ WALKER S. ASHLEY \\ Department of Geographic and Atmospheric Sciences, Northern Illinois University, DeKalb, Illinois
}

(Manuscript received 28 August 2018, in final form 13 December 2018)

\begin{abstract}
This research applies an automated mesoscale convective system (MCS) segmentation, classification, and tracking approach to composite radar reflectivity mosaic images that cover the contiguous United States (CONUS) and span a relatively long study period of 22 years (1996-2017). These data afford a novel assessment of the seasonal and interannual variability of MCSs. Additionally, hourly precipitation data from 16 of those years (2002-17) are used to systematically examine rainfall associated with radar-derived MCS events. The attributes and occurrence of MCSs that pass over portions of the CONUS east of the Continental Divide (ECONUS), as well as five author-defined subregions-North Plains, High Plains, Corn Belt, Northeast, and Mid-South - are also examined. The results illustrate two preferred regions for MCS activity in the ECONUS: 1) the Mid-South and Gulf Coast and 2) the Central Plains and Midwest. MCS occurrence and MCS rainfall display a marked seasonal cycle, with most of the regions experiencing these events primarily during the warm season (May-August). Additionally, MCS rainfall was responsible for over $50 \%$ of annual and seasonal rainfall for many locations in the ECONUS. Of particular importance, the majority of warm-season rainfall for regions with high agricultural land use (Corn Belt) and important aquifer recharge properties (High Plains) is attributable to MCSs. These results reaffirm that MCSs are a significant aspect of the ECONUS hydroclimate.
\end{abstract}

\section{Introduction}

Mesoscale convective systems (MCSs) are organized assemblages of thunderstorms that produce distinct circulations and features at a larger scale than any individual convective cell (Zipser 1982). These systems are proficient rain producers and are important drivers of energy redistribution in the atmosphere (Fritsch and Forbes 2001). MCSs, for the purposes of this research, are defined as any assemblage of thunderstorms that persists for at least $3 \mathrm{~h}$ and contain a contiguous or semicontiguous convective (reflectivity $\geq 40 \mathrm{dBZ}$ ) area with some intense $(\geq 50 \mathrm{dBZ}$ ) rainfall of at least $100 \mathrm{~km}$ along the system's major axis (Parker and Johnson 2000; Houze 2004). This definition is based on the dynamical reasoning presented by Parker and Johnson (2000)namely, the cumulative effects of convective updrafts and downdrafts interacting on scales of $100 \mathrm{~km}$ or

Corresponding author: Alex M. Haberlie, ahaberlie1@lsu.edu greater generate persistent meso- $\beta$ to meso- $\alpha$ circulations after a few hours. The time scale of the resulting circulations are on the order of hours to 1 day, which is an order of magnitude larger than a typical cell. Similar criteria as those defined by Parker and Johnson have been used in many previous MCS studies (e.g., Cohen et al. 2007; Gallus et al. 2008; Hane et al. 2008; Coniglio et al. 2010).

Research on MCS occurrence has provided evidence that these events produce a large, but variable, percentage of seasonal rainfall in many parts of the conterminous United States (CONUS) - particularly for areas east of the Continental Divide (herein, ECONUS; Fritsch et al. 1986; Kunkel et al. 1994; Doswell et al. 1996; Geerts 1998; Brooks and Stensrud 2000; Anderson and Arritt 2001; Ashley et al. 2003; Schumacher and Johnson 2006; Hitchens et al. 2012; Kunkel et al. 2012; Hitchens et al. 2013; Stevenson and Schumacher 2014). The goal of this current study is to produce and analyze an objective, automated, and radar-based climatology of MCSs 
using an unprecedented amount of data-namely, 22 years. In addition to these radar data-which are sampled every $15 \mathrm{~min}$ across the ECONUS from 1996 to 2017-quality-controlled, hourly, precipitation data (stage IV; Lin and Mitchell 2005) are used to identify the amount of precipitation produced by MCSs. Additionally, the automated approach affords the ability to objectively determine the relative importance of MCS rainfall to the hydroclimate of the ECONUS. The resulting climatology provides unique and novel insights into the seasonal and interannual variability of MCS events and their associated rainfall. This work also suggests that MCSs should be a focus of highresolution climate change studies that produce rainfall projections in ECONUS.

The body of literature relating to MCSs, with a focus on ECONUS MCS occurrence, is discussed in section 2. The generation of the climatology, as well as a discussion of the tracking and machine learning approach used to delineate MCS events in the remotely sensed data (Haberlie and Ashley 2018a,b) is provided in section 3 . Results from the radar-only climatology are discussed in section 4 , and the radarand rainfall-based climatology is discussed in section 5 . Finally, a discussion and summary of the findings is provided in section 6 .

\section{Background}

MCSs can produce an assortment of atmospheric hazards, including tornadoes (Trapp et al. 2005; Gallus et al. 2008; Smith et al. 2012), damaging nontornadic winds (Kelly et al. 1985; Johns and Hirt 1987; Ashley and Mote 2005), and flash flooding (Maddox et al. 1979; Bosart and Sanders 1981; Kunkel et al. 1994; Bell and Janowiak 1995; Doswell et al. 1996; Schumacher and Johnson 2005; Moore et al. 2012; Peters and Schumacher 2014; Gochis et al. 2015; Mallakpour and Villarini 2015). There are also many subtle ways that MCSs are disruptive to society, such as causing delays for air travel (Steiner and Krozel 2009; Pinto et al. 2015). Flooding is, in many cases, a consequence of MCS rainfall (Doswell et al. 1996; Schumacher and Johnson 2005), owed to the combination of high rainfall rates, large size compared to isolated cellular events, and sometimes slow or even back-building movement (Schumacher and Johnson 2006; Moore et al. 2012; Rahmani et al. 2016). It has been shown that MCSs produce a large percentage of observed rainfall (Houze 2004), and a nontrivial amount of extreme precipitation events in the ECONUS (Kunkel et al. 2012; Stevenson and Schumacher 2014). Conversely a lack of MCS rainfall in this region can lead to, or exacerbate, existing drought (Fritsch et al. 1986;
Hoerling et al. 2014) when the placement of the jet stream, or associated forcing necessary for development, is anomalous (Sud et al. 2003; Basara et al. 2013; Hoerling et al. 2014). Notably, MCSs and their rainfall are at least partially to blame for as many as $40 \%$ of all flooding deaths in the ECONUS (Ashley and Ashley 2008).

MCSs can develop quickly in environments with strong forcing and weak inhibition, or more slowly through the upscale growth of individual cells and subsequent cold pool dynamics (Markowski and Richardson 2010). The environment in which MCSs form and evolve can also influence the movement, morphology, and the potential impacts of the system (Blanchard 1990; Parker and Johnson 2000; Houze 2004; Gallus et al. 2008). For example, synoptic features present during the months of May and June 2010 produced repeated MCS development and flash flooding that killed dozens (Higgins et al. 2011). The early May event that affected Nashville was particularly devastating, as the passage of two quasi-stationary MCSs produced flooding that killed 26 and resulted in $\$ 3$ billion in damages (Moore et al. 2012). On the seasonal scale, Junker et al. (1999) found that 85 different MCSs during the 1993 warm season were largely responsible for disastrous flooding in the Mississippi and Missouri River basins. These are just a few illustrations, with dozens of articles in the literature exemplifying the effects MCSs and their rainfall have on society.

Much of the climatological research on MCSs has focused on a spatially large subtype known as mesoscale convective complexes (MCCs; Maddox 1980). Ashley et al. (2003) illustrated that MCC activity maximizes in the central CONUS. Additionally, they found that as much as $9 \%$ of annual rainfall was associated with MCCs for areas with highest activity, and this contribution maximized in the May-August period at $16 \%$. Other work that examined MCCs during shorter study periods reported similar results (Rodgers et al. 1985; Augustine and Howard 1988; Anderson and Arritt 1998). Although these phenomena represent the largest types of MCSs, there are numerous MCSs that do not meet MCC size criteria that also have important contributions to regional hydroclimatology. Such events can commonly occur in regions besides the central CONUS, such as in the Northeast (Lombardo and Colle 2010) and Southeast (Geerts 1998; Anderson and Arritt 2001; Pinto et al. 2015; Prein et al. 2017).

The majority of warm-season MCS events in the central CONUS attain maximum strength and/or organization during the overnight hours (Geerts et al. 2017). These events typically start over higher-elevation 
regions near the Continental Divide and propagate eastward into the Central Plains and Midwest overnight (Carbone et al. 2002). A physical mechanism that drives this pattern of increased nocturnal MCS activity is the Great Plains low-level jet (GPLLJ; Higgins et al. 1997) and the resulting latitudinal advection of moisturerich air from areas near the Gulf of Mexico. These nocturnal events are typically not surfaced-based and their predictability is an area of ongoing research (Geerts et al. 2017). In general, MCSs can develop any time thunderstorms occur in a wind shear regime that favors persistent linear organization (Rotunno et al. 1988; McNulty 1995).

\section{Data and methodology}

This study uses two primary datasets: an archive of National Operational Weather Radar (NOWrad) images and the stage IV hourly precipitation analysis (Lin and Mitchell 2005). The NOWrad dataset is a CONUSwide mosaic of composite reflectivity with approximately $2-\mathrm{km}$ spatial resolution that can be used to generate objective climatologies for precipitation events of interest (Fabry et al. 2017). The values of each grid point represent a proxy of the column-maximum instantaneous rainfall rate measured in units of $\mathrm{dBZ}$ (reflectivity). For this study, we generate a climatology of MCS occurrence using NOWrad images from 1996 to 2017 for every $15-\min$ period, and approximately $98 \%$ of these periods have available data. Stage IV data have approximately 4-km resolution, are derived from qualitycontrolled rain gauge and radar-based estimates of hourly precipitation, and have been used extensively in heavyrainfall and MCS-related studies (Hitchens et al. 2013; Clark et al. 2014). Gridcell values are the hourly rainfall rate measured in millimeters per hour. One caveat associated with the hourly stage IV data is that the quality control is less rigorous than that which is applied to the 6-h and 24-h stage IV data (Stevenson and Schumacher 2014). As a result, some spurious precipitation totals exist in the dataset. However, since MCS objects detected in the NOWrad dataset are used to spatially filter the stage IV data, the influence of potential artifacts should only have a minimal effect on the resulting MCS rainfall climatology. Because stage IV data are only available beginning in 2002, two related analyses are performed: 1) an MCS event climatology from 1996 to 2017 and 2) an MCS rainfall climatology from 2002 to 2017. To facilitate analyses that use both datasets, NOWrad and stage IV data are first regridded to an equal area grid.

Events are extracted from the NOWrad data using an MCS segmentation, classification, and tracking method (Haberlie and Ashley 2018a,b) based on the Parker and
Johnson (2000) definition. The method can be summarized in six steps:

1) Convective ( $\geq 40 \mathrm{dBZ}$ ) cells with some intense $(\geq 50 \mathrm{dBZ})$ precipitation and an area of at least $40 \mathrm{~km}^{2}$ (10 grid points) are identified in each NOWrad image.

2) These convective cells are aggregated into contiguous or semicontiguous regions of convection using a binary closing with a search radius of $24 \mathrm{~km} \mathrm{(12}$ grid points).

3) All aggregated regions of convection with a major axis length exceeding $100 \mathrm{~km}$ (50 grid points) are affiliated with stratiform precipitation within $96 \mathrm{~km}$ (48 grid points) to form "slices."

4) Fourteen basic attributes (area, mean intensity, etc.) of the resulting slices are passed into an ensemble of trained machine learning algorithms, which assigns a probabilistic classification ranging from 0 (not very MCS-like) to 1 (very MCS-like).

5) Slices with a probabilistic classification exceeding 0.95 are organized into contiguous storm tracks (swaths) using spatiotemporal overlap checking (Lakshmanan et al. 2009), with ties broken using the Hungarian method (Munkres 1957; Gagne et al. 2017). A second pass is used to connect spurious track cessations and initiations (Lakshmanan et al. 2015).

6) Swaths with durations exceeding $3 \mathrm{~h}$ are identified for time periods such as hour of the day or month of the year, and the extent of stratiform precipitation for each contained slice is used to generate spatial occurrence and to spatially filter stage IV data.

In addition to identifying MCS events, this approach reduces the inclusion of non-MCS events that may not be removed by image processing alone (i.e., steps 1-3), such as hurricanes and unorganized clusters of convective cells. For two testing years (2015 and 2016), this specific approach resulted in spatial patterns of MCS occurrence that generally agreed with the subjective identification of thousands of MCS events performed by the authors (Haberlie and Ashley 2018a) and an external dataset of MCS events during the same period (Geerts et al. 2017). Although exhaustive steps were taken to reduce the amount of non-MCS phenomena, some of these events may still be included in the analyses presented by this study. For detailed information on the segmentation, tracking, and classification approach, please see Haberlie and Ashley (2018a,b).

Precipitation associated with MCSs is identified by spatially filtering stage IV data using slice intensity 

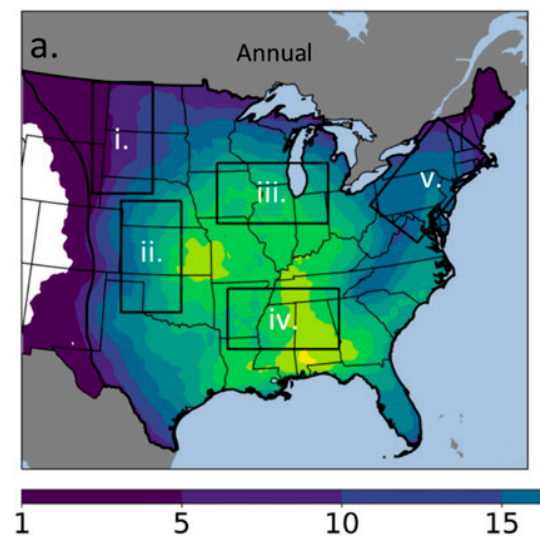

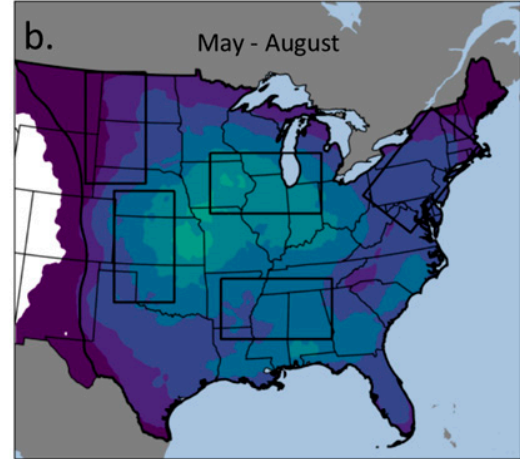

25

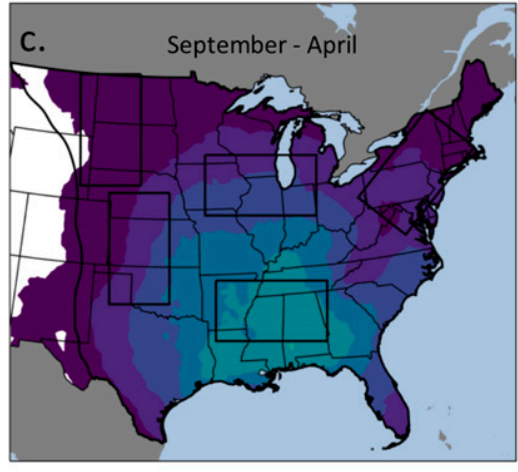

35

40

$45+$

FIG. 1. Mean MCS occurrence for (a) the entire year (January-December), (b) May-August, and (c) September-April. The five regions analyzed in this study are labeled in (a), namely, (i) North Plains, (ii) High Plains, (iii) Corn Belt, (iv) Mid-South, and (v) Northeast. Additionally, the ECONUS is denoted by all CONUS land areas east of the black line along the Continental Divide.

information within qualifying swaths identified from 2002 to 2017. The stratiform extent of each slice at the top of the hour and 15,30, and 45 min after the hour are combined to generate a binary mask associated with where the MCS was located during that period. For example, radar data from 1000, 1015, 1030, and 1045 UTC are used to spatially filter stage IV data valid at 1100 UTC. Next, the values associated with stage IV grids from the top of the following hour that are within $10 \mathrm{~km}$ of the binary mask are considered rainfall associated with that MCS. This process is repeated for each hour that the MCS existed, and then again for each qualified MCS swath. The resulting filtered hourly precipitation is thus only precipitation that was produced by a qualifying MCS swath, and all other precipitation accumulation can be removed. Finally, filtered stage IV data are summed over periods of interest (hour of day, month, etc.) to generate estimates of historical MCS rainfall.

\section{MCS occurrence}

MCS occurrence from 1996 to 2017 is calculated by counting the number of times the spatial extent of each qualifying MCS swath overlaps a gridpoint location (see section 3). Multiple MCS events can occur for the same location within a 24-h period, but two or more MCS events cannot occur at the same time in the same location. In addition to examining the ECONUS, we delineate five subregions (Fig. 1) to examine regional differences in the MCS climatology, namely, (i) North Plains, (ii) High Plains, (iii) Corn Belt, (iv) Mid-South, and (v) Northeast. Because virtually all the qualifying MCS events in this study occurred in the ECONUS (Fig. 1), the subregions are positioned east of the Continental Divide.
Locations in the ECONUS experience up to 50 mean annual MCS events. Two general maxima exist: 1) in regions of the Mid-South, including Alabama, Mississippi, Tennessee, and Kentucky, and 2) portions of the Central Plains, including Kansas and Missouri. During the growing season from May through August, portions of the Central Plains and Midwest experience the most MCSs, with a mean of 20-30 events occurring annually. This maximum is generated largely by the upscale growth of afternoon thunderstorms that initiate in favored development regions in the High Plains (Carbone et al. 2002; Ahijevych et al. 2004; Carbone and Tuttle 2008), as well as the meandering location of the GPLLJ interface with frontal boundaries (Wang and Chen 2009; Geerts et al. 2017). MCS events can also generate future MCS development through the formation of atmospheric bores, outflow boundaries, and mesoscale convective vortices (Geerts et al. 2017). The maximum in MCS activity retreats south and east from September to April, with locations in the MidSouth experiencing means of 20-30 events during these months. This maximum is caused by periodic frontal system passages that can be collocated with rich Gulf moisture (Geerts 1998; Parker and Ahijevych 2007). MCS counts in the ECONUS typically maximize during June and July, with a mean count of 111 and 108 MCS events per month, respectively (Fig. 2).

The subregions experience a markedly different yearly (Fig. 3) and hourly (Fig. 4) cycle of MCS activity. For the ECONUS, the largest increase in MCS activity occurs from late spring to late summer, with fewer events occurring in the fall and winter. For the North Plains, MCSs rarely occur before April. In contrast, MCSs commonly occur during every 


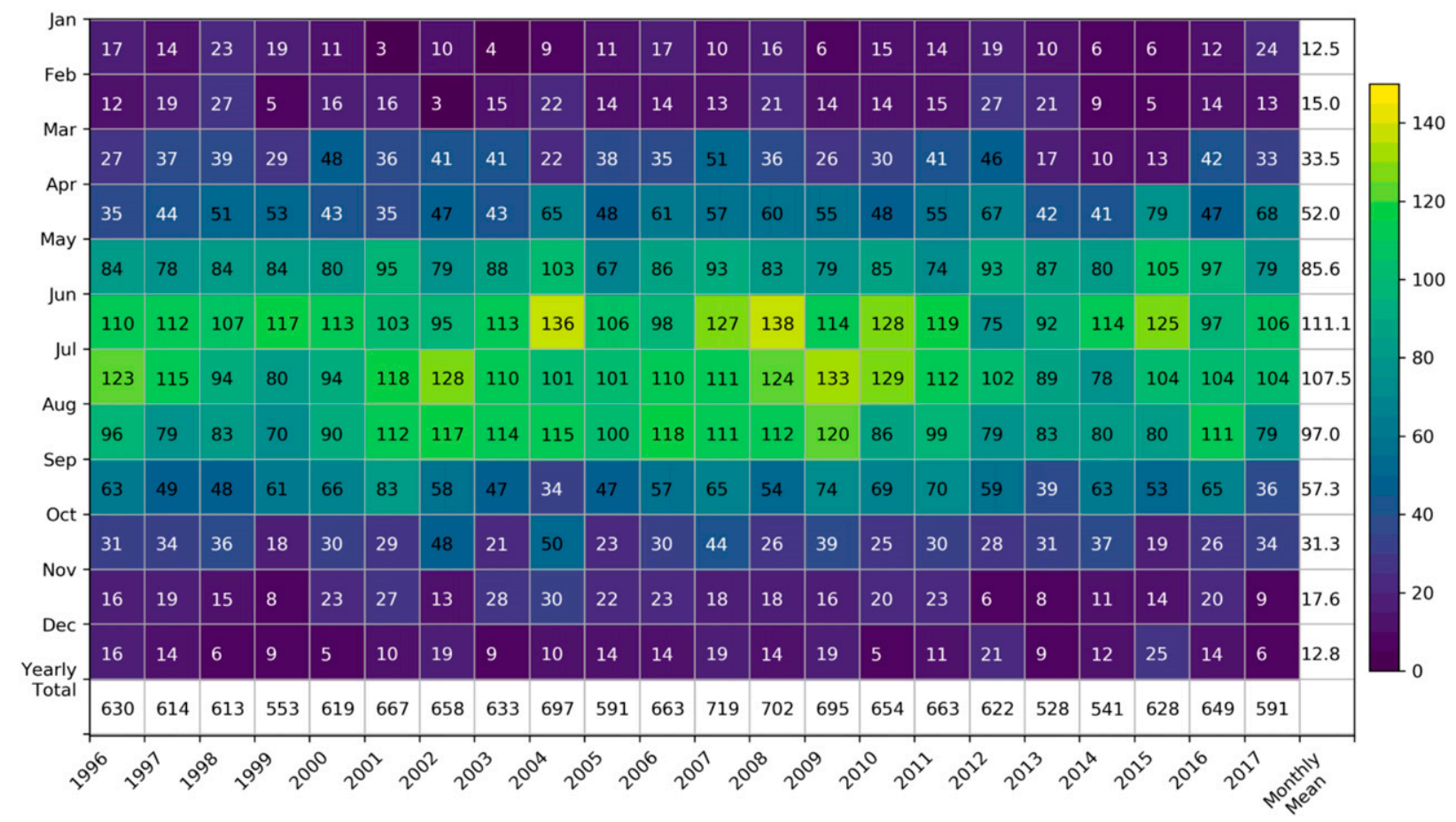

FIG. 2. Total (bottom row) yearly and (right column) monthly MCS counts, as well as monthly mean MCS counts from 1996 to 2017 for the ECONUS, which is identified in Fig. 1.

month in the Mid-South. In absolute counts, the MidSouth experiences the most interannual variability (Table 1). However, relative to the mean annual count of MCS occurrence, the Northeast experiences the most interannual variability. Based on mean annual counts, locations in the Mid-South experience the most MCS passages, followed by, in descending order, the Corn Belt, the High Plains, the Northeast, and the North Plains. For the Mid-South, annual MCS counts range from 79 (2000) to 157 (2009). In contrast, the North Plains experienced a low MCS count of 19 (2017) and a high of 43 (2007). These varied counts are largely owed to the seasonality of MCS occurrence in these regions. These values compare well to previous studies. For example, Geerts (1998) found that 398 MCSs-163 of those were intense MCSs that are likely most similar to the events identified in this studyoccurred in the southeast CONUS between May 1994 and April 1995. The most comparable region used in this study, the Mid-South, experiences an annual mean of 106 MCSs. Over the CONUS, Pinto et al. (2015) identified 873 unique MCSs in 2012 and 929 MCSs in 2013 during June, July, and August. In comparison, this study found 256 and 264 MCS events during the same months in 2012 and 2013, respectively, over the ECONUS. On the other hand,
Murray and Colle (2011) identified between 8 and 26 "convective streaks" - which can be used as proxies for MCS occurrence (Carbone et al. 2002) -in the Northeast during the warm seasons (April-September) between 1996 and 2007. During the same years and months, the present study found that between 19 and 60 MCSs occurred in the Northeast. Prein et al. (2017), using stage IV data from 2001 to 2013, identified a mean of approximately 60 June-August MCS events per year occurring in the Midwest, whereas the present study identified a mean of approximately $50 \mathrm{MCS}$ events per year within the Corn Belt during the same months. The difference between the numbers presented by those studies and the current study are likely owed to different segmentation approaches (Haberlie and Ashley 2018b), study area sizes, and the datasets used.

The diurnal cycle of MCS activity during the MayAugust period varies between the regions examined in this study (Fig. 4). The High Plains experiences elevated MCS activity during the late evening and overnight hours (0300-0700 UTC) with a peak at 0600 UTC. In comparison, the Corn Belt experiences an almost constant risk of MCS activity between 0100 and 1300 UTC, with a maximum around 1100 UTC. These results are similar to the findings presented by previous 

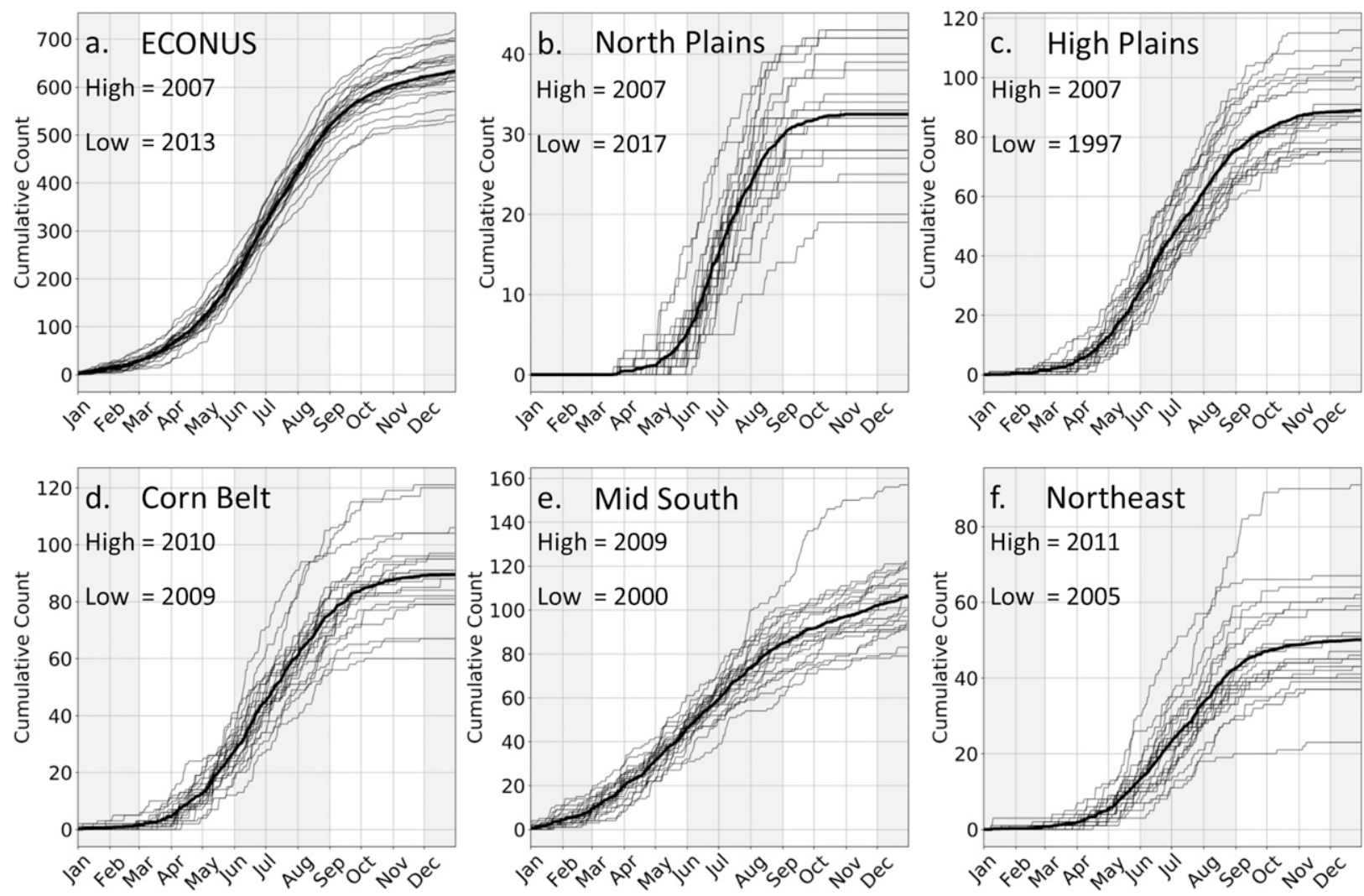

FIG. 3. Cumulative MCS counts for each day of the year for (a) ECONUS, (b) North Plains, (c) High Plains, (d) Corn Belt, (e) MidSouth, and (f) Northeast. For each panel, the years with the highest and lowest MCS counts are noted. Lines represent cumulative MCS counts for each year from 1996 to 2017, and the thick line represents the mean over this period.

work (Carbone and Tuttle 2008), and are thought to be associated with favored initiation zones (High Plains) and the dissipation-reinitiation zones (Corn Belt) for MCSs. The results are also similar to those reported by Lombardo and Colle (2010), who found that linear and nonlinear systems in the Northeast typically developed between 1800 and 0000 UTC. Additionally, Geerts (1998) noted a relative minimum in southeastern CONUS MCS activity from 0400 to 1800 UTC, which also is in agreement with the findings reported in Fig. 4.

MCS attributes varied between seasons and subregions (Fig. 5). For the ECONUS, the mean annual MCS slice area during the study period is approximately $54000 \mathrm{~km}^{2}$, and the mean MCS slice area during the May-August period $\left(47000 \mathrm{~km}^{2}\right)$ was less than the mean MCS slice area during the September-April pe$\operatorname{riod}\left(64000 \mathrm{~km}^{2}\right)$. Although the same relative seasonality in mean MCS slice area is apparent for all regions, annual-mean subregion MCS slice area is the largest in the Mid-South $\left(67000 \mathrm{~km}^{2}\right)$, and lowest in the North Plains $\left(38000 \mathrm{~km}^{2}\right)$. For the May-August period, the Corn Belt experiences the largest MCSs $\left(55000 \mathrm{~km}^{2}\right)$, whereas the North Plains experiences the smallest
MCSs $\left(38000 \mathrm{~km}^{2}\right)$. For the September-April period, the Mid-South experiences the largest MCSs $\left(85000 \mathrm{~km}^{2}\right)$, and the North Plains experiences the smallest MCSs $\left(39000 \mathrm{~km}^{2}\right)$.

MCS slices generally have longer major axis lengths in the September-April period $(566 \mathrm{~km})$ compared to the May-August period $(453 \mathrm{~km})$. The Corn Belt experiences MCS slices with the longest major axis lengths during the May-August period $(489 \mathrm{~km})$, and the Mid-South experiences MCS slices with the longest major axis lengths during the September-April period $(695 \mathrm{~km})$. On average, MCS slices are more circular during the May-August period compared to the September-April period. These differences may be owed to the predominant lifting mechanisms during the cool season (e.g., strong synoptic forcing; Burke and Schultz 2004; Dial et al. 2010) and warm season (e.g., cold pools; Weisman and Rotunno 2004).

These values are consistent with previous automated analyses of mesoscale precipitation features. For example, Prein et al. (2017) reported a mean precipitation intensity of around $10 \mathrm{~mm} \mathrm{~h}^{-1}(35-40 \mathrm{dBZ})$ using a minimum threshold of $5 \mathrm{~mm} \mathrm{~h}^{-1}(30-35 \mathrm{~dB} Z)$, which are both slightly higher than the mean intensity $(31.5 \mathrm{dBZ})$ 


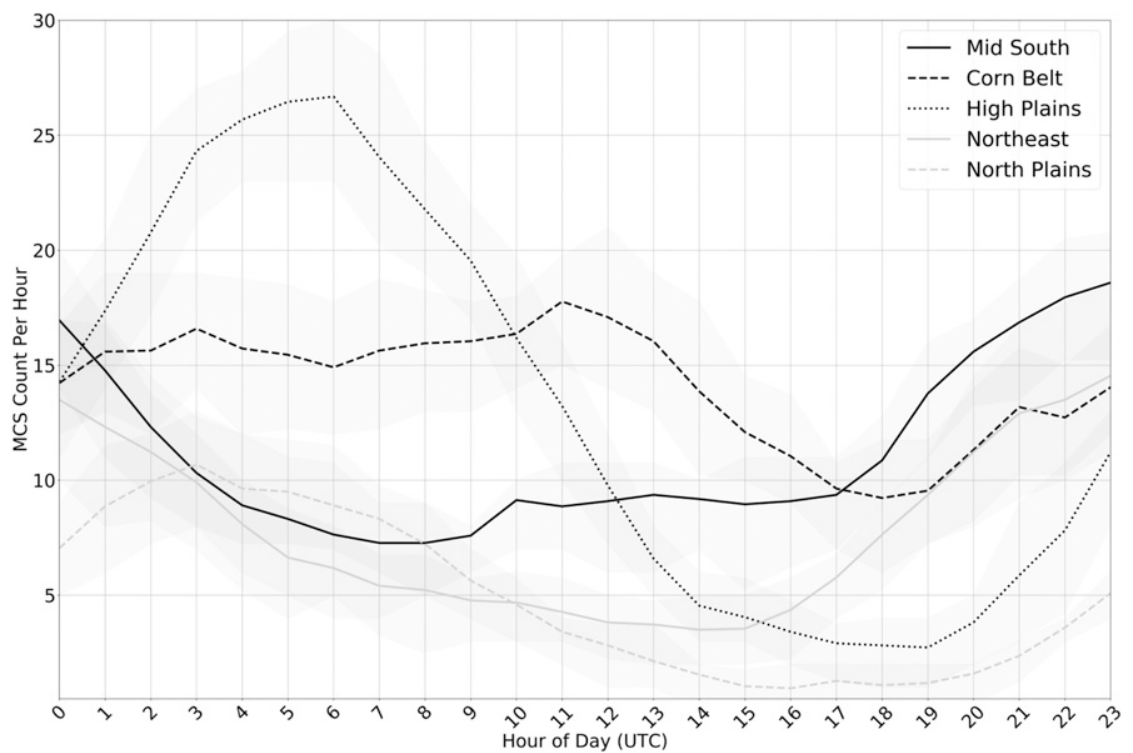

FIG. 4. Mean count of MCSs per hour for each May-August period from 1996 to 2017 for the regions examined in this study. The shaded regions (light gray fill) around each line represent the interquartile range (i.e., 25 th-75th percentiles), which denotes variability among the MayAugust periods.

and minimum threshold $(20 \mathrm{~dB} Z)$ for this study. The areas associated with MCS events are consistent with the range of $10000-1000000 \mathrm{~km}^{2}$ reported in the literature (Hitchens et al. 2012; Fiollieau and Roca 2013; Prein et al. 2017). Additionally, the horizontal dimension of major axis lengths (between 100 and $1000 \mathrm{~km}$ ) is consistent with the theoretical length range for MCSs (Markowski and Richardson 2010).

\section{MCS rainfall}

As was the case with the spatial occurrence of MCSs, precipitation associated with MCSs has two maxima along the Gulf Coast as well as parts of Kansas and Missouri (Fig. 6). These regions experience, on average, over $500 \mathrm{~mm}$ of MCSs rainfall per year. However, the seasonality of MCSs and their rainfall produces these maxima at different times of the year. For some locations in the Central Plains and Midwest, a mean of up to $350-400 \mathrm{~mm}$ of MCS precipitation accumulates during the May-August period, whereas locations along the Gulf Coast only experience up to 250 $300 \mathrm{~mm}$. This pattern flips during the SeptemberApril period, where some locations in the Mid-South and along the Gulf Coast experience $400 \mathrm{~mm}$ or greater of mean MCS rainfall during these months.

TABLE 1. Total annual MCS counts for portions of the ECONUS and each subregion. Boldface (italic) font denotes maximum (minimum) values for the given region. Included are means and coefficient of variations (CV) for all years and regions.

\begin{tabular}{|c|c|c|c|c|c|c|c|c|c|c|c|c|}
\hline Region & 1996 & 1997 & 1998 & 1999 & 2000 & 2001 & 2002 & 2003 & 2004 & 2005 & 2006 & 2007 \\
\hline ECONUS & 630 & 614 & 613 & 553 & 619 & 667 & 658 & 633 & 697 & 591 & 663 & 719 \\
\hline North Plains & 25 & 35 & 33 & 31 & 39 & 33 & 32 & 27 & 28 & 42 & 20 & 43 \\
\hline High Plains & 91 & 72 & 85 & 85 & 89 & 87 & 76 & 76 & 100 & 102 & 87 & 116 \\
\hline Corn Belt & 88 & 67 & 97 & 81 & 96 & 95 & 88 & 79 & 90 & 89 & 120 & 104 \\
\hline Mid-South & 122 & 112 & 92 & 95 & 79 & 119 & 97 & 111 & 121 & 93 & 107 & 94 \\
\hline \multirow[t]{2}{*}{ Northeast } & 52 & 37 & 64 & 45 & 59 & 51 & 46 & 51 & 61 & 23 & 47 & 58 \\
\hline & 2008 & 2009 & 2010 & 2011 & 2012 & 2013 & 2014 & 2015 & 2016 & 2017 & Mean & $\mathrm{CV}$ \\
\hline ECONUS & 702 & 695 & 654 & 663 & 622 & 528 & 541 & 628 & 649 & 591 & 633 & 0.08 \\
\hline North Plains & 34 & 38 & 42 & 43 & 24 & 28 & 28 & 31 & 40 & 19 & 33 & 0.22 \\
\hline High Plains & 97 & 110 & 85 & 76 & 76 & 87 & 75 & 106 & 100 & 79 & 89 & 0.14 \\
\hline Corn Belt & 106 & 60 & 121 & 95 & 67 & 79 & 82 & 84 & 91 & 91 & 90 & 0.17 \\
\hline Mid-South & 119 & 157 & 101 & 114 & 111 & 83 & 91 & 107 & 100 & 107 & 106 & 0.15 \\
\hline Northeast & 67 & 62 & 43 & 91 & 45 & 40 & 41 & 43 & 37 & 39 & 50 & 0.27 \\
\hline
\end{tabular}



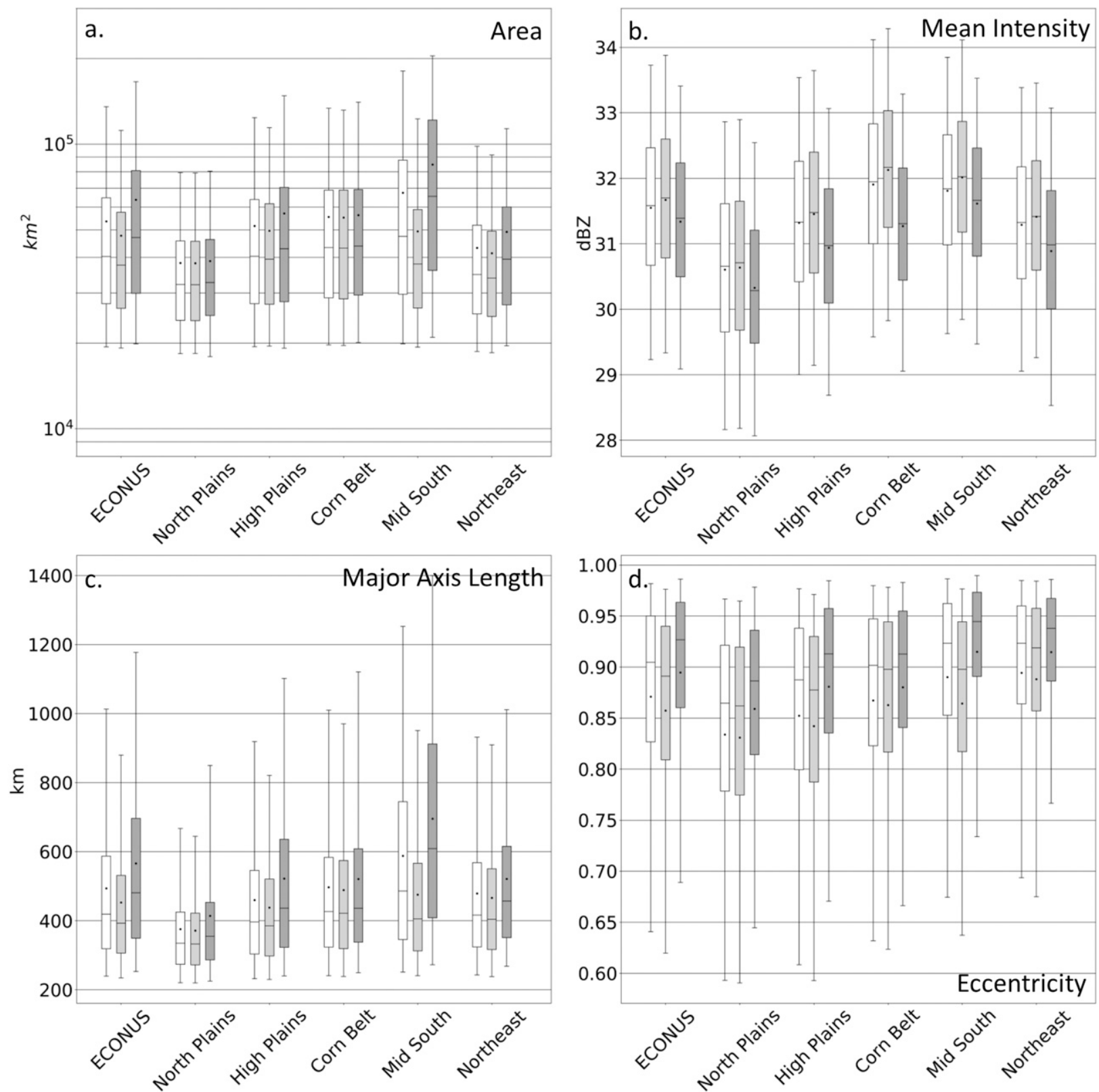

FIG. 5. Distribution of values for four select variables associated with MCS events that passed through each region, namely, (a) area, (b) mean intensity, (c) major axis length, and (d) eccentricity. Attributes for the entire year are denoted by white boxes, May-August values are denoted by light gray boxes, and September-April values are denoted by dark gray boxes. The box represents the interquartile range (IQR), with the black horizontal line denoting the distribution's median and the black dot denoting the mean. The whiskers represent the 5th and 95th percentiles.

MCSs can account for over $40 \%$ of yearly rainfall in portions of the Central Plains, and over $30 \%$ of yearly rainfall for many locations between the Continental Divide and the Appalachian Mountains. During the May-August period, some locations in Kansas rely on MCSs for over $60 \%$ of their precipitation, and much of the Central Plains and Midwest receive over $50 \%$ of their precipitation from
MCSs. During the September-April period, places along the Gulf Coast regularly receive over $30 \%$ of their precipitation from MCSs. Although this study is the first to provide a high-resolution, long-term climatology of the relative contribution of MCS rainfall to total rainfall, the percentages agree with short-term or longitudinally aggregated values reported by previous work (Fritsch et al. 1986; Carbone and Tuttle 2008). 

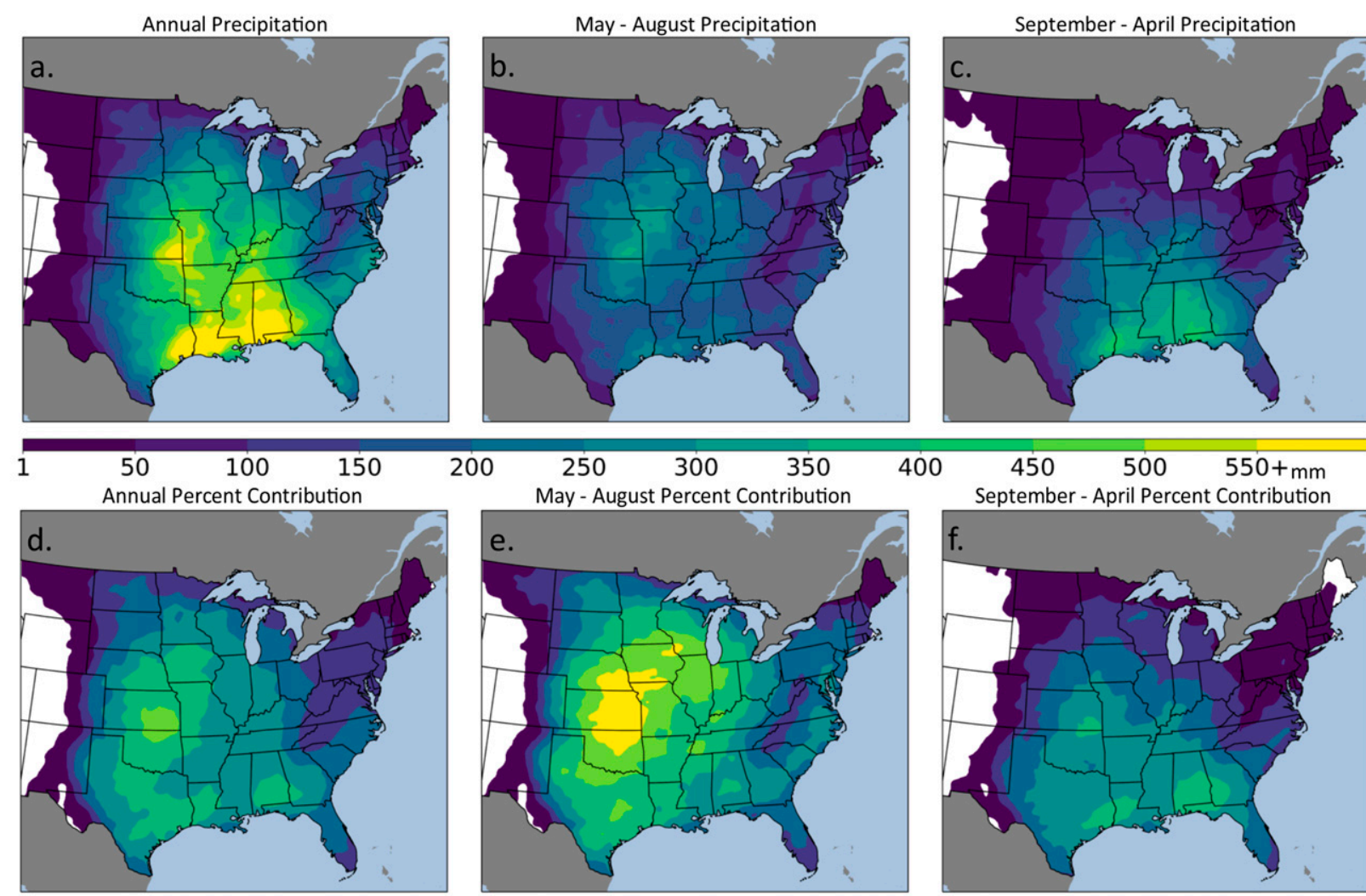

$500 \quad 550+\mathrm{mm}$ September - April Percent Contribution

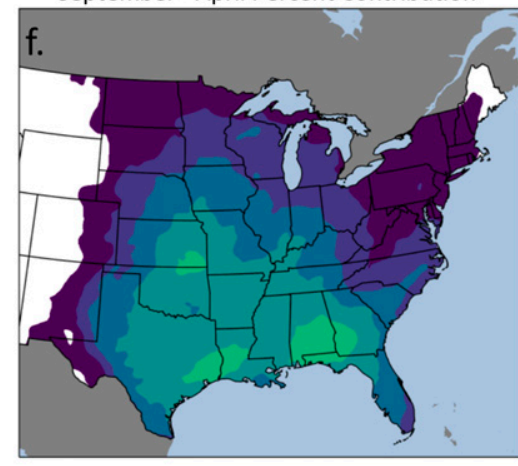

$1 \%$ $10 \%$ $20 \%$ $30 \%$ $40 \%$

$50 \%$

$60 \%+$

FIG. 6. Mean MCS precipitation totals $(\mathrm{mm})$ and percentage contribution of MCS rainfall to total rainfall for (a),(d) the entire year (January-December), (b),(e) May-August, and (c),(f) September-April.

Previous MCS studies have provided evidence that these events attain maximum strength during the overnight hours in the central CONUS during the warm season (Carbone et al. 2002; Carbone and Tuttle 2008; Geerts et al. 2017). Indeed, most of the rainfall associated with MCSs during the May-August period occurred between 0400 and 1200 UTC (Fig. 7). By the 1200-2000 UTC period, the characteristic western flank of a high-to-low gradient of mean precipitation moves east, illustrating the propagating nature of MCSs and their rainfall, forced by mid- and upper-level steering winds (Cotton et al. 1983). Between 2000 and 0400 UTC, the redevelopment of MCSs, as evidenced by the westward expansion of mean MCS rainfall, can be noted in the climatology. Remarkably, over $70 \%$ of rainfall that occurs between 0400 and 1200 UTC in portions of Kansas, Oklahoma, and Nebraska during the May-August period is generated by MCSs. Although this percentage drops off considerably by $1200-2000$ and $2000-0400$ UTC, many locations in the central CONUS owe MCSs for over
$40 \%$ of their mean rainfall totals during the warm season.

Annual cumulative MCS precipitation volume exhibits spatially distinct magnitudes and seasonality (Table 2; Fig. 8). In general, the greatest increase in cumulative precipitation volume occurs during the May-August period. For the ECONUS, mean annual MCS precipitation volume is $1398 \mathrm{~km}^{3}$, with a range from $1139 \mathrm{~km}^{3}$ (2005) to $1639 \mathrm{~km}^{3}$ (2008). In comparison, mean annual total rainfall volume for the ECONUS is $4739 \mathrm{~km}^{3}$, with a range from $3951 \mathrm{~km}^{3}$ (2012) to $5626 \mathrm{~km}^{3}$ (2015). The mean annual contribution of MCS rainfall to total precipitation volume for the ECONUS is around $30 \%$, which reached a minimum in 2013 (24\%) and a maximum in 2008 (34\%). On average, the MidSouth experiences the most MCS precipitation $\left(169 \mathrm{~km}^{3}\right)$ as well as the most overall precipitation $\left(446 \mathrm{~km}^{3}\right)$, with a mean annual MCS contribution of approximately $38 \%$, and a range from $30 \%$ (2013) to $47 \%$ (2008). The North Plains experiences the lowest mean precipitation volume associated with MCSs at $26 \mathrm{~km}^{3}$, with a range from $12 \mathrm{~km}^{3}$ (2006) to $39 \mathrm{~km}^{3}$ 

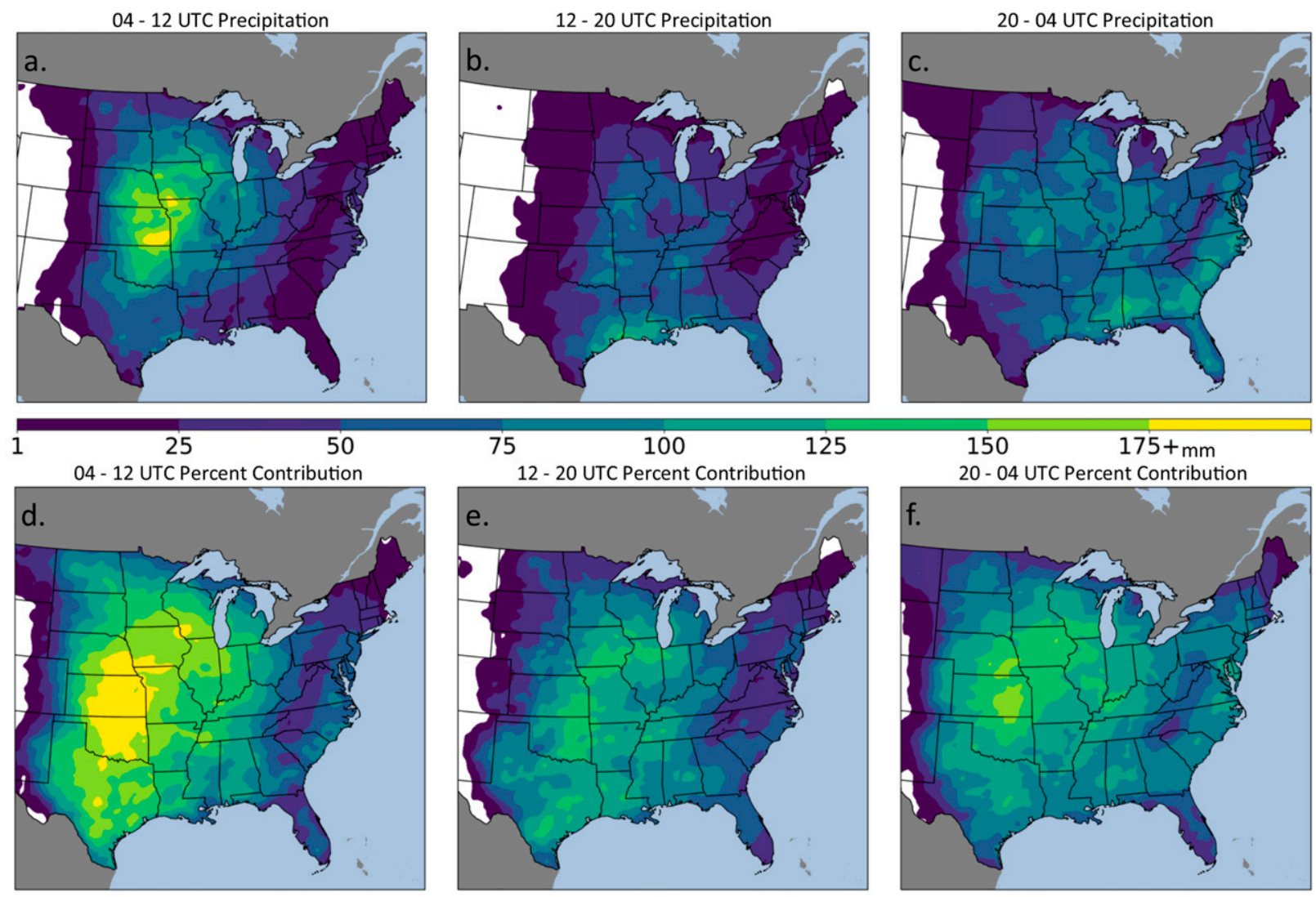

$1 \%$

$10 \%$

$20 \%$

$30 \%$

$40 \%$

$50 \%$

$60 \%$

$70 \%+$

FIG. 7. As in Fig. 6, but for May-August for the following periods: (a),(d) 0400-1200, (b),(e) 1200-2000, and (c),(f) 2000-0400 UTC.

(2007). Although the Northeast experiences more precipitation from MCSs $\left(48 \mathrm{~km}^{3}\right)$ compared to the North Plains, the contribution of MCS precipitation to total precipitation is the lowest of all regions (12\%).
Similarly, the High Plains experiences a largest percent of mean annual precipitation from MCSs (42\%) relative to all the subregions, despite experiencing less total MCS precipitation $\left(92 \mathrm{~km}^{3}\right)$ compared to the

TABLE 2. Total annual overall (All) and MCS precipitation volume $\left(\mathrm{km}^{3}\right)$ for portions of the ECONUS and each subregion. Boldface (italic) font denotes maximum (minimum) values for given combination of region and precipitation category.

\begin{tabular}{|c|c|c|c|c|c|c|c|c|c|c|c|c|c|c|c|c|c|c|}
\hline \multirow[b]{2}{*}{ Region } & \multicolumn{2}{|c|}{2002} & \multicolumn{2}{|c|}{2003} & \multicolumn{2}{|c|}{2004} & \multicolumn{2}{|c|}{2005} & \multicolumn{2}{|c|}{2006} & \multicolumn{2}{|c|}{2007} & \multicolumn{2}{|c|}{2008} & \multicolumn{2}{|c|}{2009} & \multicolumn{2}{|c|}{2010} \\
\hline & MCS & All & MCS & All & MCS & All & MCS & All & MCS & All & MCS & All & MCS & All & MCS & All & MCS & All \\
\hline ECONUS & 1505 & 4760 & 1259 & 4424 & 1357 & 4832 & 1139 & 4274 & 1229 & 4427 & 1455 & 4416 & 1639 & 4843 & 1554 & 5003 & 1486 & 4495 \\
\hline North Plains & 22 & 85 & 14 & 104 & 18 & 132 & 36 & 144 & 12 & 112 & 39 & 149 & 33 & 175 & 30 & 162 & 38 & 172 \\
\hline High Plains & 71 & 168 & 70 & 164 & 80 & 221 & 97 & 222 & 67 & 200 & 137 & 261 & 108 & 248 & 92 & 227 & 99 & 224 \\
\hline Corn Belt & 95 & 245 & 94 & 273 & 118 & 310 & 84 & 255 & 101 & 328 & 140 & 334 & 142 & 379 & 94 & 345 & 158 & 334 \\
\hline Mid-South & 175 & 574 & 175 & 458 & 148 & 460 & 118 & 359 & 166 & 417 & 121 & 323 & 212 & 450 & 246 & 570 & 161 & 359 \\
\hline \multirow[t]{2}{*}{ Northeast } & 51 & 342 & 40 & 384 & 54 & 393 & 19 & 391 & 50 & 468 & 52 & 365 & 66 & 416 & 49 & 360 & 34 & 369 \\
\hline & \multicolumn{2}{|c|}{2011} & \multicolumn{2}{|c|}{2012} & \multicolumn{2}{|c|}{2013} & \multicolumn{2}{|c|}{2014} & \multicolumn{2}{|c|}{2015} & \multicolumn{2}{|c|}{2016} & \multicolumn{2}{|c|}{2017} & \multicolumn{2}{|c|}{ Mean } & \multicolumn{2}{|c|}{$\mathrm{CV}$} \\
\hline ECONUS & 1529 & 4630 & 1286 & 3951 & 1221 & 5043 & 1306 & 4955 & 1396 & 5626 & 1559 & 5005 & 1450 & 5134 & 1398 & 4739 & 0.10 & 0.08 \\
\hline North Plains & 31 & 189 & 17 & 121 & 28 & 212 & 23 & 200 & 33 & 190 & 33 & 191 & 13 & 150 & 26 & 156 & 0.34 & 0.23 \\
\hline High Plains & 74 & 183 & 67 & 148 & 91 & 216 & 96 & 208 & 114 & 287 & 116 & 239 & 94 & 245 & 92 & 216 & 0.21 & 0.17 \\
\hline Corn Belt & 113 & 316 & 71 & 225 & 105 & 336 & 115 & 355 & 103 & 369 & 127 & 341 & 111 & 340 & 111 & 318 & 0.20 & 0.14 \\
\hline Mid-South & 211 & 449 & 170 & 384 & 149 & 493 & 160 & 449 & 154 & 502 & 159 & 413 & 173 & 473 & 169 & 446 & 0.19 & 0.15 \\
\hline Northeast & 91 & 488 & 49 & 329 & 39 & 355 & 45 & 381 & 44 & 353 & 34 & 317 & 46 & 377 & 48 & 380 & 0.32 & 0.12 \\
\hline
\end{tabular}



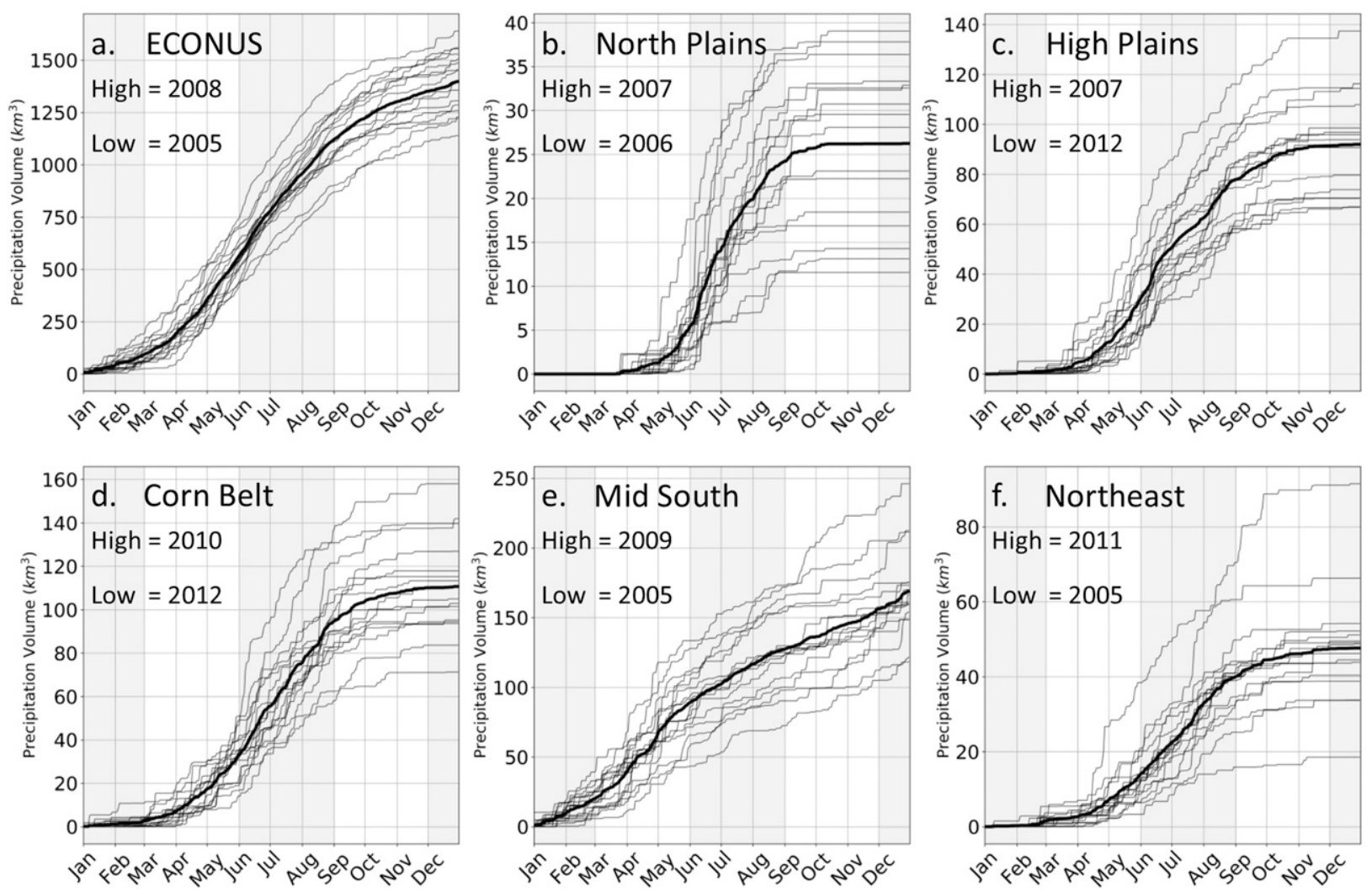

FIG. 8. As in Fig. 3, but for cumulative MCS precipitation volume $\left(\mathrm{km}^{3}\right)$ from 2002 to 2017.

Mid-South. The contribution of MCS rainfall to total rainfall for the High Plains ranges from 34\% (2006) to $53 \%$ (2007).

The percentage contribution of MCS rainfall to total rainfall varies greatly in time and space (Fig. 9). For the ECONUS, the percentage contribution per month varies from 14\% (December) to $40 \%$ (June), and generally increases quickly during the spring while slowly decreasing during the summer and into the fall. For every month in the Mid-South, the percentage contribution of MCS rainfall to total rainfall exceeds $25 \%$ on average. However, the High Plains and Corn Belt experience a slightly greater magnitude in June (62\%) and July (61\%), respectively, compared to the peak percentage contribution in the Mid-South in April (59\%). The North Plains experiences the strongest seasonality, with less than $1 \%$ of total precipitation generated by MCSs in NovemberFebruary, compared to a high of $31 \%$ in June. Of particular interest for agricultural applications (Changnon and Kunkel 1999; Tannura et al. 2008; Mishra and Cherkauer 2010), the Corn Belt typically experiences greater than $50 \%$ of its total rainfall from MCSs in June-August, and this monthly contribution did not drop below $30 \%$ for any year within the duration of the study period.

\section{Discussion and summary}

This work represents the longest radar-based climatology of MCSs for the ECONUS. Using 22 years (19962017) of mosaics of composite reflectivity, MCSs are tracked using image analysis and machine learning methods as described in Haberlie and Ashley (2018a,b). Additionally, this MCS climatology encompasses multiple annual to multiyear teleconnection oscillations, such as El Niño-Southern Oscillation (Allen et al. 2018) and the North Atlantic Oscillation (Önskog et al. 2018), and is approaching the typical 30 -yr period used to calculate climate normals. Using hourly precipitation data to supplement the radar data during a 16 -yr period (2002-17), MCS rainfall is systematically analyzed to objectively determine the importance of these events to ECONUS and regional hydroclimates. The results represent an objective, fully automated, and reproducible MCS climatology that can be used in applied climatology, resiliency, and mitigation studies, and as a baseline to compare climate change projections. 

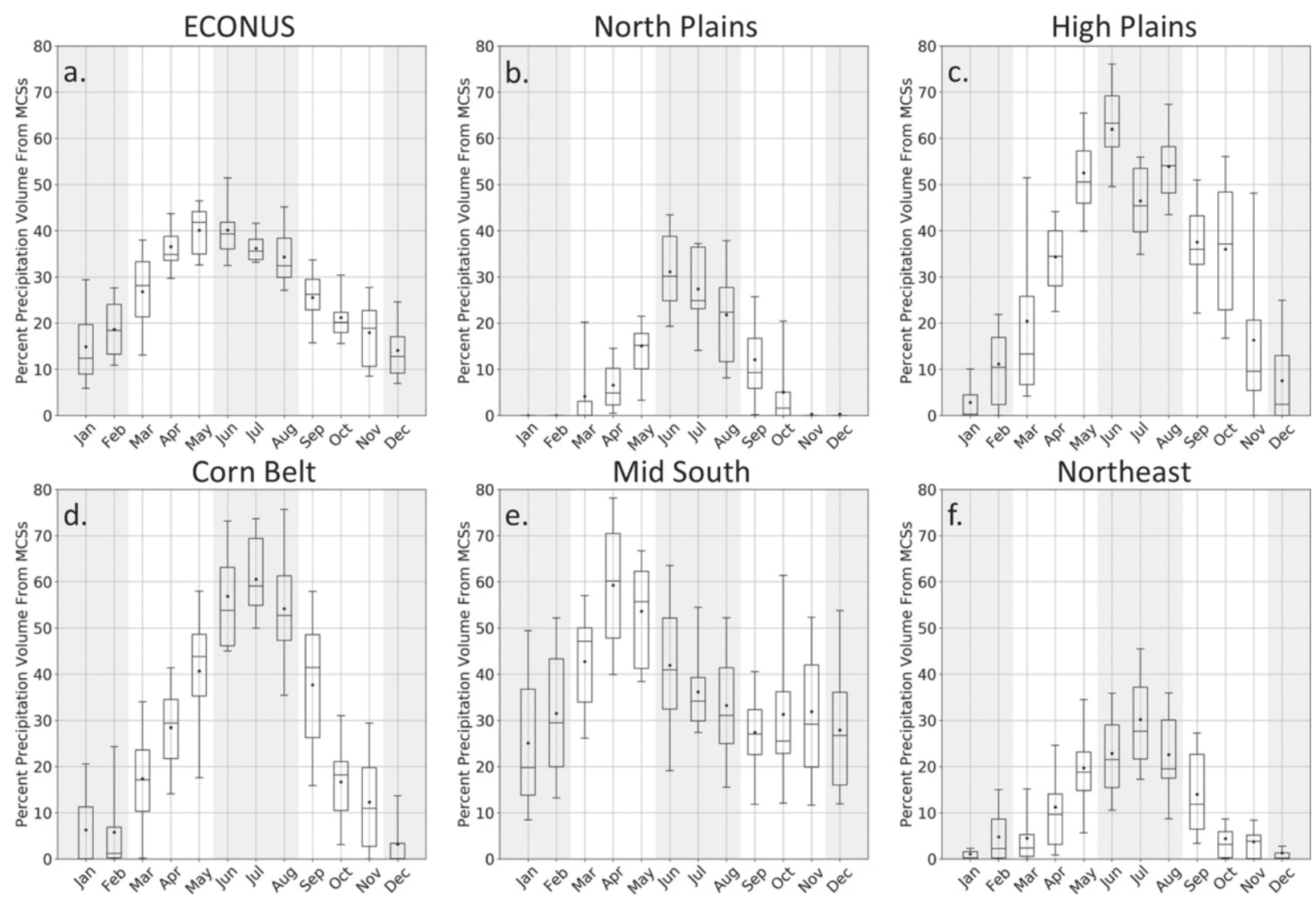

FIG. 9. The percentage contribution of MCS precipitation volume to total precipitation volume for each month of the year for 2002-17. The box represents the IQR, with the black horizontal line denoting the distribution's median and the black dot denoting the mean. The whiskers represent the 5th and 95th percentiles.

MCSs are primarily an ECONUS phenomenon (Fig. 1). Warm-season (May-August) occurrence is maximized in the Central Plains and Midwest, and cool-season (September-April) occurrence is maximized in the Mid-South. In general, the Mid-South and the Corn Belt experience the most MCSs, and the North Plains and Northeast experience the fewest (Fig. 10). MCS rainfall also maximizes in the central and southern CONUS, with some locations experiencing over $500 \mathrm{~mm}$ of MCS rainfall during any given year (Fig. 6). Warm-season contribution of MCS rainfall to total rainfall exceeds $50 \%$ for many locations in the central CONUS and Midwest. Nocturnal MCS rainfall (0400-1200 UTC) can exceed $175 \mathrm{~mm}$ for portions of Kansas during the warm season, and this rainfall can account for over $60 \%-80 \%$ in the central CONUS and Midwest during this time of the day (Fig. 7). This percentage contribution varies over the course of a year, with most locations in the ECONUS experiencing the largest percentage contribution of MCS rainfall to total rainfall during the warm season (Fig. 9). Some regions, like the
Mid-South, have a somewhat constant contribution of MCS rainfall during every month of the year, whereas the North Plains only experience MCS rainfall during the months of April-October. Because of this, the Mid-South experiences the highest cumulative MCS rainfall, whereas the North Plains experiences the lowest cumulative MCS rainfall (Fig. 10).

MCSs represent a significant portion of total annual rainfall. This contribution maximizes for regions that have high agricultural (Corn Belt) and water resource (High Plains) considerations. During the primary growing season in the Corn Belt (June-August; Tannura et al. 2008), MCS rainfall generally accounts for over $50 \%$ of rainfall. Additionally, in critical recharge regions for the Ogallala Aquifer (McGuire 2014), MCS rainfall accounts for over $40 \%$ of warmseason rainfall. Because of the relative importance of MCS rainfall, studies that examine or produce these high-resolution climate simulations should be a priority for CONUS-based climate scientists (e.g., Prein et al. 2017). 

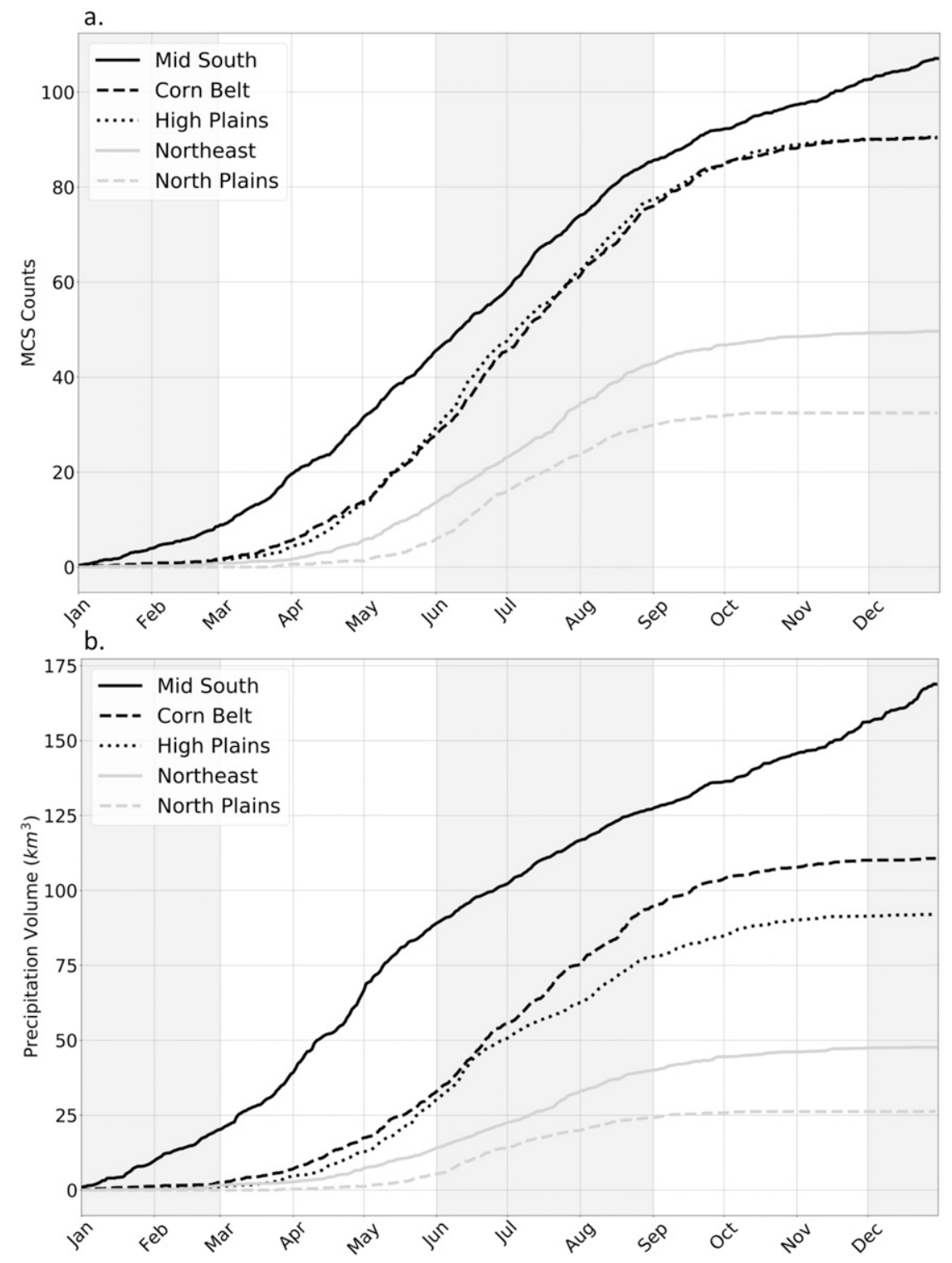

FIG. 10. (a) Mean cumulative MCS counts and (b) mean cumulative MCS precipitation volume for the examined subregions from 2002 to 2017.

Acknowledgments. We thank Drs. Russ Schumacher (Colorado State University), Victor Gensini (NIU), David Changnon (NIU), Thomas Pingel (NIU), and Jie Zhou (NIU) for their suggestions and insight that improved the research and paper. We also want to thank Arthur Person (senior research assistant at The Pennsylvania State University, Department of Meteorology) for providing computational resources. Finally, we thank Dr. Xin-Zhong Liang and two anonymous reviewers who helped improve this manuscript. This research was supported by National Science Foundation Grant ATM-1637225, an NIU Division of Research and Innovation Partnerships Research and Artistry Grant, and an NIU Graduate School Dissertation
Completion Fellowship. This work used resources of the Center for Research Computing and Data at Northern Illinois University. The code and instructions on how to download the processed data used in this paper are available at https://github.com/ahaberlie/MCS. Stage IV data used for this paper were downloaded from https://rda.ucar. edu/datasets/ds507.5/.

\section{REFERENCES}

Ahijevych, D. A., C. A. Davis, R. E. Carbone, and J. D. Tuttle, 2004: Initiation of precipitation episodes relative to elevated terrain. J. Atmos. Sci., 61, 2763-2769, https://doi.org/10.1175/ JAS3307.1. 
Allen, J. T., M. J. Molina, and V. A. Gensini, 2018: Modulation of annual cycle of tornadoes by El Niño-Southern Oscillation. Geophys. Res. Lett., 45, 5708-5717, https://doi.org/10.1029/ 2018GL077482.

Anderson, C. J., and R. W. Arritt, 1998: Mesoscale convective complexes and persistent elongated convective systems over the United States during 1992 and 1993. Mon. Wea. Rev., 126, 578-599, https://doi.org/10.1175/1520-0493(1998)126<0578: MCCAPE $>2.0 . \mathrm{CO} ; 2$.

_ and _ 2001: Mesoscale convective systems over the United States during the 1997-98 El Niño. Mon. Wea. Rev., 129, 2443-2457, https://doi.org/10.1175/1520-0493(2001)129<2443: MCSOTU $>2.0 . \mathrm{CO} ; 2$.

Ashley, S. T., and W. S. Ashley, 2008: Flood fatalities in the United States. J. Appl. Meteor. Climatol., 47, 805-818, https://doi.org/ 10.1175/2007JAMC1611.1.

Ashley, W. S., and T. L. Mote, 2005: Derecho hazards in the United States. Bull. Amer. Meteor. Soc., 86, 1577-1592, https://doi.org/10.1175/BAMS-86-11-1577.

,, P. G. Dixon, S. L. Trotter, E. J. Powell, J. D. Durkee, and A. J. Grundstein, 2003: Distribution of mesoscale convective complex rainfall in the United States. Mon. Wea. Rev., 131, 3003-3017, https://doi.org/10.1175/1520-0493(2003)131<3003: DOMCCR $>2.0 . \mathrm{CO} ; 2$.

Augustine, J. A., and K. W. Howard, 1988: Mesoscale convective complexes over the United States during 1985. Mon. Wea. Rev., 116, 685-701, https://doi.org/10.1175/1520-0493(1988)116<0685: MCCOTU $>2.0 . \mathrm{CO} ; 2$.

Basara, J. B., J. N. Maybourn, C. M. Peirano, J. E. Tate, P. J. Brown, J. D. Hoey, and B. R. Smith, 2013: Drought and associated impacts in the Great Plains of the United StatesA review. Int. J. Geosci., 4, 72-81, https://doi.org/10.4236/ ijg.2013.46A2009.

Bell, G. D., and J. E. Janowiak, 1995: Atmospheric circulation associated with the Midwest floods of 1993. Bull. Amer. Meteor. Soc., 76, 681-695, https://doi.org/10.1175/1520-0477 (1995) 076<0681:ACAWTM>2.0.CO;2.

Blanchard, D. O., 1990: Mesoscale convective patterns of the southern High Plains. Bull. Amer. Meteor. Soc., 71, 994-1005, https://doi. org/10.1175/1520-0477(1990)071<0994:MCPOTS > 2.0.CO;2.

Bosart, L. F., and F. Sanders, 1981: The Johnstown Flood of July 1977: A long-lived convective system. J. Atmos. Sci., 38, 1616-1642, https://doi.org/10.1175/1520-0469(1981)038<1616: TJFOJA $>2.0 . \mathrm{CO} ; 2$.

Brooks, H. E., and D. J. Stensrud, 2000: Climatology of heavy rain events in the United States from hourly precipitation observations. Mon. Wea. Rev., 128, 1194-1201, https://doi.org/ 10.1175/1520-0493(2000)128<1194:COHREI > 2.0.CO;2.

Burke, P. C., and D. M. Schultz, 2004: A 4-yr climatology of coldseason bow echoes over the continental United States. Wea. Forecasting, 19, 1061-1074, https://doi.org/10.1175/811.1.

Carbone, R. E., and J. D. Tuttle, 2008: Rainfall occurrence in the U.S. warm season: The diurnal cycle. J. Climate, 21, 41324146, https://doi.org/10.1175/2008JCLI2275.1.

, - - D. A. Ahijevych, and S. B. Trier, 2002: Inferences of predictability associated with warm season precipitation episodes. J. Atmos. Sci., 59, 2033-2056, https://doi.org/10.1175/ 1520-0469(2002)059<2033:IOPAWW>2.0.CO;2.

Changnon, S. A., and K. E. Kunkel, 1999: Rapidly expanding uses of climate data and information in agriculture and water resources: Causes and characteristics of new applications. Bull. Amer. Meteor. Soc., 80, 821-830, https://doi.org/10.1175/ 1520-0477(1999)080<0821:REUOCD>2.0.CO;2.
Clark, A. J., R. G. Bullock, T. L. Jensen, M. Xue, and F. Kong, 2014: Application of object-based time-domain diagnostics for tracking precipitation systems in convection-allowing models. Wea. Forecasting, 29, 517-542, https://doi.org/ 10.1175/WAF-D-13-00098.1.

Cohen, A. E., M. C. Coniglio, S. F. Corfidi, and S. J. Corfidi, 2007: Discrimination of mesoscale convective system environments using sounding observations. Wea. Forecasting, 22, 1045-1062, https://doi.org/10.1175/WAF1040.1.

Coniglio, M. C., J. Y. Hwang, and D. J. Stensrud, 2010: Environmental factors in the upscale growth and longevity of MCSs derived from rapid update cycle analyses. Mon. Wea. Rev., 138, 3514-3539, https://doi.org/10.1175/2010MWR3233.1.

Cotton, W. R., R. L. George, P. J. Wetzel, and R. L. McAnelly, 1983: A long-lived mesoscale convective complex. Part I: The mountain-generated component. Mon. Wea. Rev., 111, 1893-1918, https://doi.org/10.1175/1520-0493(1983)111<1893: ALLMCC $>2.0 . \mathrm{CO} ; 2$.

Dial, G. L., J. P. Racy, and R. L. Thompson, 2010: Short-term convective mode evolution along synoptic boundaries. Wea. Forecasting, 25, 1430-1446, https://doi.org/10.1175/ 2010WAF2222315.1.

Doswell, C. A., H. E. Brooks, and R. A. Maddox, 1996: Flash flood forecasting: An ingredients-based methodology. Wea. Forecasting, 11, 560-581, https://doi.org/10.1175/1520-0434(1996)011<0560: FFFAIB $>2.0 . \mathrm{CO} ; 2$.

Fabry, F., V. Meunier, B. P. Treserras, A. Cournoyer, and B. Nelson, 2017: On the climatological use of radar data mosaics: Possibilities and challenges. Bull. Amer. Meteor. Soc., 98, 2135-2148, https://doi.org/10.1175/BAMS-D-15-00256.1.

Fiolleau, T., and R. Roca, 2013: An algorithm for the detection and tracking of tropical mesoscale convective systems using infrared images from geostationary satellite. IEEE Trans. Geosci. Remote Sens., 51, 4302-4315, https://doi.org/10.1109/ TGRS.2012.2227762.

Fritsch, J. M., and G. S. Forbes, 2001: Mesoscale convective systems. Severe Convective Storms, Meteor. Monogr., No. 50, Amer. Meteor. Soc., 323-358.

__ R. J. Kane, and C. R. Chelius, 1986: The contribution of mesoscale convective weather systems to the warm-season precipitation in the United States. J. Appl. Meteor. Climatol., 25, 1333-1345, https://doi.org/10.1175/1520-0450 (1986) $025<1333$ :TCOMCW $>2.0$. CO 2 .

Gagne, D. J., A. McGovern, S. E. Haupt, R. A. Sobash, J. K. Williams, and M. Xue, 2017: Storm-based probabilistic hail forecasting with machine learning applied to convectionallowing ensembles. Wea. Forecasting, 32, 1819-1840, https:// doi.org/10.1175/WAF-D-17-0010.1.

Gallus, W. A., N. A. Snook, and E. V. Johnson, 2008: Spring and summer severe weather reports over the Midwest as a function of convective mode: A preliminary study. Wea. Forecasting, 23, 101-113, https://doi.org/10.1175/ 2007WAF2006120.1.

Geerts, B., 1998: Mesoscale convective systems in the southeast United States during 1994-95: A survey. Wea. Forecasting, 13, 860-869, https://doi.org/10.1175/1520-0434(1998)013<0860: MCSITS $>2.0 . \mathrm{CO} ; 2$.

, and Coauthors, 2017: The 2015 Plains Elevated Convection at Night field project. Bull. Amer. Meteor. Soc., 98, 767-786, https://doi.org/10.1175/BAMS-D-15-00257.1.

Gochis, D., and Coauthors, 2015: The Great Colorado Flood of September 2013. Bull. Amer. Meteor. Soc., 96, 1461-1487, https://doi.org/10.1175/BAMS-D-13-00241.1. 
Haberlie, A. M., and W. S. Ashley, 2018a: A method for identifying mesoscale convective systems in radar mosaics. Part I: Segmentation and classification. J. Appl. Meteor. Climatol., 57, 1575-1598, https://doi.org/10.1175/JAMC-D-17-0293.1.

_ , and _ 2018b: A method for identifying midlatitude mesoscale convective systems in radar mosaics. Part II: Tracking. J. Appl. Meteor. Climatol., 57, 1599-1621, https://doi.org/ 10.1175/JAMC-D-17-0294.1.

Hane, C. E., J. A. Haynes, D. L. Andra, and F. H. Carr, 2008: The evolution of morning convective systems over the U.S. Great Plains during the warm season. Part II: A climatology and the influence of environmental factors. Mon. Wea. Rev., 136, 929-944, https://doi.org/10.1175/2007MWR2016.1.

Higgins, R. W., Y. Yao, E. S. Yarosh, J. E. Janowiak, and K. C. Mo, 1997: Influence of the Great Plains low-level jet on summertime precipitation and moisture transport over the central United States. J. Climate, 10, 481-507, https://doi.org/10.1175/ 1520-0442(1997)010<0481:IOTGPL > 2.0.CO;2.

——, V. E. Kousky, and P. Xie, 2011: Extreme precipitation events in the south-central United States during May and June 2010: Historical perspective, role of ENSO, and trends. J. Hydrometeor., 12, 1056-1070, https://doi.org/ 10.1175/JHM-D-10-05039.1.

Hitchens, N. M., M. E. Baldwin, and R. J. Trapp, 2012: An object-oriented characterization of extreme precipitationproducing convective systems in the midwestern United States. Mon. Wea. Rev., 140, 1356-1366, https://doi.org/ 10.1175/MWR-D-11-00153.1.

—, H. E. Brooks, and R. S. Schumacher, 2013: Spatial and temporal characteristics of heavy hourly rainfall in the United States. Mon. Wea. Rev., 141, 4564-4575, https://doi.org/ 10.1175/MWR-D-12-00297.1.

Hoerling, M., J. Eischeid, A. Kumar, R. Leung, A. Mariotti, K. Mo, S. Schubert, and R. Seager, 2014: Causes and predictability of the 2012 Great Plains drought. Bull. Amer. Meteor. Soc., 95 , 269-282, https://doi.org/10.1175/BAMS-D-13-00055.1.

Houze, R. A., 2004: Mesoscale convective systems. Rev. Geophys., 42, RG4003, https://doi.org/10.1029/2004RG000150.

Johns, R. H., and W. D. Hirt, 1987: Derechos: Widespread convectively induced windstorms. Wea. Forecasting, 2, 32-49, https://doi.org/10.1175/1520-0434(1987)002<0032: DWCIW $>2.0 . \mathrm{CO} ; 2$.

Junker, N. W., R. S. Schneider, and S. L. Fauver, 1999: A study of heavy rainfall events during the Great Midwest Flood of 1993. Wea. Forecasting, 14, 701-712, https://doi.org/ 10.1175/1520-0434(1999)014<0701:ASOHRE > 2.0.CO;2.

Kelly, D. L., J. T. Schaefer, and C. A. Doswell, 1985: Climatology of nontornadic severe thunderstorm events in the United States. Mon. Wea. Rev., 113, 1997-2014, https://doi.org/ 10.1175/1520-0493(1985)113<1997:CONSTE > 2.0.CO;2.

Kunkel, K. E., S. A. Changnon, and J. R. Angel, 1994: Climatic aspects of the 1993 upper Mississippi River basin flood. Bull. Amer. Meteor. Soc., 75, 811-822, https://doi.org/ 10.1175/1520-0477(1994)075<0811:CAOTUM > 2.0.CO;2.

, D. R. Easterling, D. Kristovich, B. Gleason, L. Stoecker, and R. Smith, 2012: Meteorological causes of the secular variations in observed extreme precipitation events for the conterminous United States. J. Hydrometeor., 13, 1131-1141, https://doi.org/ 10.1175/JHM-D-11-0108.1.

Lakshmanan, V., K. Hondl, and R. Rabin, 2009: An efficient, general-purpose technique for identifying storm cells in geospatial images. J. Atmos. Oceanic Technol., 26, 523-537, https://doi.org/10.1175/2008JTECHA1153.1.
, B. Herzog, and D. Kingfield, 2015: A method for extracting postevent storm tracks. J. Appl. Meteor. Climatol., 54, 451-462, https://doi.org/10.1175/JAMC-D-14-0132.1.

Lin, Y., and K. E. Mitchell, 2005: The NCEP stage II/ IV hourly precipitation analyses: Development and applications. Preprints, 19th Conf. on Hydrology, San Diego, CA, Amer. Meteor. Soc., 1.2, http://ams.confex.com/ams/pdfpapers/ 83847.pdf.

Lombardo, K. A., and B. A. Colle, 2010: The spatial and temporal distribution of organized convective structures over the Northeast and their ambient conditions. Mon. Wea. Rev., 138, 4456-4474, https://doi.org/10.1175/2010MWR3463.1.

Maddox, R. A., 1980: Mesoscale convective complexes. Bull. Amer. Meteor. Soc., 61, 1374-1387, https://doi.org/10.1175/ 1520-0477(1980)061<1374:MCC>2.0.CO;2.

- C. F. Chappell, and L. R. Hoxit, 1979: Synoptic and meso- $\alpha$ scale aspects of flash flood events. Bull. Amer. Meteor. Soc., 60, 115-123, https://doi.org/10.1175/1520-0477-60.2.115.

Mallakpour, I., and G. Villarini, 2015: The changing nature of flooding across the central United States. Nat. Climate Change, 5, 250-254, https://doi.org/10.1038/nclimate2516.

Markowski, P., and Y. Richardson, 2010: Mesoscale convective systems. Mesoscale Meteorology in Midlatitudes, P. Markowski and Y. Richardson, Eds., John Wiley \& Sons, Ltd, 245-272.

McGuire, V. L., 2014: Water-level changes and change in water in storage in the High Plains aquifer, predevelopment to 2013 and 2011-13. U.S. Geological Survey Scientific Investigations Rep. 2014-5218, 14 pp., http://pubs.usgs.gov/sir/2014/5218/pdf/ sir2014_5218.pdf.

McNulty, R. P., 1995: Severe and convective weather: A central region forecasting challenge. Wea. Forecasting, 10, 187-202, https://doi.org/10.1175/1520-0434(1995)010<0187: SACWAC $>2.0 . C O ; 2$.

Mishra, V., and K. A. Cherkauer, 2010: Retrospective droughts in the crop growing season: Implications to corn and soybean yield in the midwestern United States. Agric. For. Meteor., 150, 10301045, https://doi.org/10.1016/j.agrformet.2010.04.002.

Moore, B. J., P. J. Neiman, F. M. Ralph, and F. E. Barthold, 2012: Physical processes associated with heavy flooding rainfall in Nashville, Tennessee, and vicinity during 1-2 May 2010: The role of an atmospheric river and mesoscale convective systems. Mon. Wea. Rev., 140, 358-378, https://doi.org/10.1175/ MWR-D-11-00126.1.

Munkres, J., 1957: Algorithms for the assignment and transportation problems. J. Soc. Ind. Appl. Math., 5, 32-38, https:// doi.org/10.1137/0105003.

Murray, J. C., and B. A. Colle, 2011: The spatial and temporal variability of convective storms over the northeast United States during the warm season. Mon. Wea. Rev., 139, 992-1012, https://doi.org/10.1175/2010MWR3316.1.

Önskog, T., C. L. E. Franzke, and A. Hannachi, 2018: Predictability and non-Gaussian characteristics of the North Atlantic Oscillation. J. Climate, 31, 537-554, https://doi.org/10.1175/JCLID-17-0101.1.

Parker, M. D., and R. H. Johnson, 2000: Organizational modes of midlatitude mesoscale convective systems. Mon. Wea. Rev., 128, 3413-3436, https://doi.org/10.1175/1520-0493(2001)129<3413: OMOMMC $>2.0 . \mathrm{CO} ; 2$.

- , and D. A. Ahijevych, 2007: Convective episodes in the eastcentral United States. Mon. Wea. Rev., 135, 3707-3727, https:// doi.org/10.1175/2007MWR2098.1.

Peters, J. M., and R. S. Schumacher, 2014: Objective categorization of heavy-rain-producing MCS synoptic types by rotated prin- 
cipal component analysis. Mon. Wea. Rev., 142, 1716-1737, https://doi.org/10.1175/MWR-D-13-00295.1.

Pinto, J. O., J. A. Grim, and M. Steiner, 2015: Assessment of the High-Resolution Rapid Refresh model's ability to predict mesoscale convective systems using object-based evaluation. Wea. Forecasting, 30, 892-913, https://doi.org/10.1175/ WAF-D-14-00118.1.

Prein, A. F., C. Liu, K. Ikeda, R. Bullock, R. M. Rasmussen, G. J. Holland, and M. Clark, 2017: Simulating North American mesoscale convective systems with a convection-permitting climate model. Climate Dyn., https://doi.org/10.1007/s00382017-3993-2, in press.

Rahmani, V., S. L. Hutchinson, J. A. Harrington Jr., and J. M. S. Hutchinson, 2016: Analysis of frequency and magnitude of extreme rainfall events with potential impacts on flooding: A case study from the central United States. Int. J. Climatol., 36, 3578-3587, https://doi.org/10.1002/joc.4577.

Rodgers, D. M., M. J. Magnano, and J. H. Arns, 1985: Mesoscale convective complexes over the United States during 1983. Mon. Wea. Rev., 113, 888-901, https://doi.org/10.1175/ 1520-0493(1985)113<0888:MCCOTU>2.0.CO;2.

Rotunno, R., J. B. Klemp, and M. L. Weisman, 1988: A theory for strong, long-lived squall lines. J. Atmos. Sci., 45, 463-485, https:// doi.org/10.1175/1520-0469(1988)045<0463:ATFSLL>2.0.CO;2.

Schumacher, R. S., and R. H. Johnson, 2005: Organization and environmental properties of extreme-rain-producing mesoscale convective systems. Mon. Wea. Rev., 133, 961-976, https://doi.org/10.1175/MWR2899.1.

$\longrightarrow$, and - 2006: Characteristics of U.S. extreme rain events during 1999-2003. Wea. Forecasting, 21, 69-85, https://doi.org/ 10.1175/WAF900.1.

Smith, B. T., R. L. Thompson, J. S. Grams, C. Broyles, and H. E. Brooks, 2012: Convective modes for significant severe thunderstorms in the contiguous United States. Part I: Storm classification and climatology. Wea. Forecasting, 27, 11141135, https://doi.org/10.1175/WAF-D-11-00115.1.

Steiner, M., and J. Krozel, 2009: Translation of ensemble-based weather forecasts into probabilistic air traffic capacity impact. Proc. 2009 Digital Avionics Systems Conf., Orlando, FL, Institute of Electrical and Electronics Engineers, 2.D.6-1-2.D.6-7.

Stevenson, S. N., and R. S. Schumacher, 2014: A 10-year survey of extreme rainfall events in the central and eastern United States using gridded multisensor precipitation analyses. Mon. Wea. Rev., 142, 3147-3162, https://doi.org/10.1175/ MWR-D-13-00345.1.

Sud, Y. C., D. M. Mocko, K.-M. Lau, and R. Atlas, 2003: Simulating the midwestern U.S. drought of 1988 with a GCM. J. Climate, 16, 3946-3965, https://doi.org/10.1175/1520-0442(2003)016<3946: STMUDO $>2.0 . \mathrm{CO} ; 2$.

Tannura, M. A., S. H. Irwin, and D. L. Good, 2008: Weather, technology, and corn and soybean yields in the U.S. Corn Belt. Marketing and Outlook Research Rep. 2008-01, Dept. of Agricultural and Consumer Economics, University of Illinois at Urbana-Champaign, Urbana, IL, 123 pp.

Trapp, R. J., S. A. Tessendorf, E. S. Godfrey, and H. E. Brooks, 2005: Tornadoes from squall lines and bow echoes. Part I: Climatological distribution. Wea. Forecasting, 20, 23-34, https:// doi.org/10.1175/WAF-835.1.

Wang, S., and T. Chen, 2009: The late-spring maximum of rainfall over the U.S. central plains and the role of the lowlevel jet. J. Climate, 22, 4696-4709, https://doi.org/10.1175/ 2009JCLI2719.1.

Weisman, M. L., and R. Rotunno, 2004: "A theory for strong longlived squall lines" revisited. J. Atmos. Sci., 61, 361-382, https:// doi.org/10.1175/1520-0469(2004)061<0361:ATFSLS > 2.0.CO;2.

Zipser, E. J., 1982: Use of a conceptual model of the life-cycle of mesoscale convective systems to improve very short-range forecasts. Nowcasting, K. A. Browning, Ed., Academic Press, 191-204. 